\title{
The Effect of Organizational Culture On Lecturers' Job Satisfaction and Performance (A Research in Muhammadiyah University throughout East Java)
}

\author{
Etta Mamang Sangadji \\ Departemen of Economic Education \\ STKIP PGRI Pasuruan \\ J1. Kihadjar Dewantoro 27-29, Indonesia \\ Telp.(0343)421-985,E-mail:sangadji_23@yahoo.com \\ SOPIAH, \\ Dept. Of Management, State University of Malang, \\ Jl. Semarang 5, Malang 65145, Indonesia \\ Telp. (0341) 552-888, E-mail: sopiahsangadji@ymail.com
}

\author{
Accepted: March 01, 2013 Published: May 09, 2013 \\ Doi:10.5296/ijld.v3i3.3673 URL: http://dx.doi.org/10.5296/ijld.v3i3.3673
}

\begin{abstract}
This study aimed to clarify the effect of organizational culture on job satisfaction and its impact on lecturers' performance. The population of the study is the lecturers of the Muhammadiyah University throughout East Java namely 1881 people, with random sampling it was obtained a sample of 200 people. For collecting data, questionnaires and interviews were used. Data analysis techniques applied SEM (Structural Equation Modeling) with the use of AMOS software. The results showed that: (1) Organizational culture has positive and significant effect on lecturers' job satisfaction (2) Job satisfaction has positive and significant effect on lecturers' performance (3) Organizational culture has positive and significant impact on lecturers' performance (4) Organizational culture has positive and significant effect to lecturers' performance through job satisfaction.
\end{abstract}

Key Words: Organizational Culture, Lecturers' Job Satisfaction and Performance

\section{Introduction}

The study of the effect of organizational culture on an individual's performance or the performance of an organization is always interesting to study. Robbins (2000) suggests the attitude or behavior of members of the organization in general is strongly influenced by the value system embraced within an organization. According Nimran (1999) organizational culture derived from experience, past history, beliefs, values and norms, however, are also highly strategic leadership role in establishing the performance of the organization, let alone in developing countries. Even the organizational culture is often also derived from the culture of a nation and a religion. Weber (2001) states that the advanced and modern Germans in the world of industry and economy driven more by Calling culture that originates in the Protestant ethic led by Martin Luther leadership which further inspires entrepreneurs to build a modern and advanced economic system The essence of the Protestant doctrine is that working is not merely an economic activity but more than that he is a man's spiritual needs and goals. Therefore laziness is a dangerous threat to man's spiritual. The ethics of this Calfinis then have a dominant role in coloring the culture of business and non-business organizations in Germany. Subsequently Robert N. Bellah in Madjid (1999) suggested that the advanced and modern 
Japanese in economic and industry is also affected by national culture (Samurai culture) which was later adopted by business organizations to be the culture of business organizations in Japan. Bellah suggested a link between the dynamic between Tokugawa religion and the rise of Japan's modern economy. Japan's modern economic ethics sourced from ethical Samurai class which serves as the backbone of renewal Meiji (1868 -1911). The essence of Samurai culture is that (1) organization must not only preoccupied with minor issues, but instead of focusing on management of large enterprises (2) once you start a business, rest assured that you will be successful (3) do not involve themselves in the business -speculative business (4) execute all the business in the spirit of national interest (6) continue to increase the quality of service to the buyer (7) work hard, live simply and caring for others (8) use the appropriate personnel (8) treat employees well (9) to be hard and firm at the time of starting a business, but be careful and detail about business continuity.

The study of the effect of Islamic culture and ethos as well as commitment to economic progress leaders have been conducted by Bobock (in Madjid, 1987) inspired by the study of Weber. The study was conducted in East Africa in particular on Muslim immigrants from Indo Pakistan. Bocock, studying the role of the Muslim immigrant from Syiah Ismailiah sect, especially Indo Pakistan that plays an important role in economic development, pioneering crafting trade and industry and dominating financial world. Results of his study concluded that the religious spirit is very important in encouraging their work culture. Another study about the effect of the Islamic teachings and merchants pioneering (leadership) on economic and industrial development is also conducted by Clifford Geertz in Indonesia, in Abdullah (1979) which concluded that the economic progress achieved modernist Muslims (Muhammadiyah members) in the cities of research, Kota Gede Yogyakarta and Pekalongan concluded the presence of equation Islamic ethics and Protestant spirit that animates Islamic merchants who succeed as an entrepreneur. Islamic culture has encouraged creating a healthy organizational culture, such as discipline, honesty, saving, respect for others and the belief that work is worship. Besides hand over or giving is better than the lower hand or begging.

Recent study on the effects of culture on performance can be seen from the research of Daniel Denison of the University of Michigan Business School found a clear relation between organizational culture (which is determined by Denison as mission, involvement, consistency, and adaptability) and business performance (as noticed from profitability, ROA, sales, market share, product development, quality and job satisfaction). In his research for 15 years on more than 1,000 companies in the industrial sector and the public sector showed the same consistency (Juechter, et.al. 1998). Meanwhile Deal \& Kennedy (1982) and Peter \& Waterman (1982) in Sobirin (1997) who focused their research on American companies emphasize the importance of shared beliefs and values to achieve organizational effectiveness. They claimed that the success or failure of an organization lies in the absence of a strong culture of the organization. The reason: the performance of the individual and organizational performance, and how the sense of belonging of the employees toward company can not be properly understood except by understanding its culture. Meanwhile, a study conducted by Mercer with research object 305 Chief Executive Officer (CEO) of various industries in the USA showed that CEOs do not debate the role they played in shaping the culture of the organization (Dessler 1992). Among them (97\%) agree that the value of strong organization, confidence, organizational attitudes, attitudes of employees and how the manager works, it is important for organizational success. Furthermore 94\% agreed that the values of corporate culture is influenced by top management. While in education, research tries to reveal the effect of culture on satisfaction and its impact on performance has not been done.

The question is whether the studies conducted above also apply in Indonesia? In this study the authors tried to conduct research on the effect of organizational culture on lecturers' job satisfaction and performance at Muhammadiyah University of East Java. As a developing country, efforts to improve performance or job satisfaction of organizational members both in business and in non-business organizations such as the organization of 
education is a very important thing to study. There is a strong presumption that organizational culture variables greatly affect the performance of a person in an organization, this is proved by several studies that the authors have pointed out above. Do the results of the study also apply among Muhammadiyah organization especially the institutions of higher education? What is meant by organizational culture here is a common value system held and developed by members of the organization that distinguishes it from other organizations. This value system is a set of main and overall characteristics as the culture of organization that represent common perceptions of organization members and guides the behavior of both the organization as a whole and in its parts (Robbins, 2003).

Muhammadiyah University is a Islamic values-based university, therefore organizational culture and organizational commitment of university leadership prevailing is different from another university organizational culture based on the other value. In formulating the college objectives, Muhammadiyah University in general has the aims including: (1) produce a noble Muslim scholar, proficient, believing in himself, useful to the nation, and charity towards the realization of the main society, just and prosperous blessed by Allah SWT (2) promote and develop the science to the development of society and the Republic of Indonesia. (Qai'dah of Muhammadiyah Compilation, 2002). The objective of the formulation is clear that organizational culture developed in order to achieve these objectives, in addition to base itself on modern organizational culture will not be separated from Islamic values base. While job satisfaction is: a general attitude of a person toward his work. A person with a high level of job satisfaction will demonstrate a positive attitude towards his work otherwise if low levels of work satisfaction then he will show a negative attitude on his work. Furthermore Robbins (2003), expressed the attitude of employees towards work is a reflection of the level of satisfaction he felt from the job.

In this study the main theoretical basis for organizational cultural variables used the theory proposed by Recardo and Jolly (2003) concerned about planning, communication, training and development, benefits, decision-making, risk-taking, while the management practices of the Islamic perspective of organizational culture theory used is derived from Ali Shariati (1999) about the motivation to work, worship order, discipline and appreciate the time and Watanabe (2005) about the egalitarian spirit and sincerity. For variables of job satisfaction study, the theory used is: Job Description Ifidex theory (JDI) proposed by Wood, et al (1988) that there are five aspects of the Job Description Index (JDI) to measure job satisfaction in terms of where it should have the attention of the manager JDI to the fifth aspect of job satisfaction include: the work itself, the quality of supervision, relationships with co-workers, promotional opportunities, and pay. From JDI then combined with the Index of Work Satisfaction (IWS), which contains about six aspects to measure the level of job satisfaction (in Jernigen III, Beggs, and Kohut 2002). Six aspects include: autonomy, interaction, pay, professional status, organizational policies, and task requirements. If both opinions above are united then there are 11 sub-variable of job satisfaction that include: policy / administration organization, supervision, working conditions, interpersonal relations, salary, job security, job performance, responsibility, opportunity to grow / develop, recognition, the work itself. Furthermore performance is intended as a result of behavior that is judged by some criterion or standard of quality of the work. Martoyo (1994) states that performance is the level of work performance of employees and potential employees in their efforts to develop themselves to the interests of the company or organization. Simamora (1995), the performance is the level to which the employee reaches the job requirements. Bernardin and Russel (1993), performance is a record of achievement resulting from a particular job function or activity during a specific time period. Moenir (1983), individual performance is the result of a person on the unity of time and a certain size. In this study the authors to measure lecturers' performance using performance measures issued by the Director General of Higher Education Ministry DIKNAS 
Indonesia (2002), which consists of education and teaching, research, social service and other supporting activities.

The reason for the research on the lecturers at the University of Muhammadiyah in East Java are: (1) there is still very limited research done in the world of Islamic-based education that tries to reveal the effect of organizational culture and leadership commitment to the satisfaction and performance. It there has been a research, only adopting established Western theories and did not touch or take Islamic values which is actually a real life practice of Indonesian society. In this study there is an attempt to mix theories from the West and the theories that were born from the conception of Islam (2) Muhammadiyah University in East Java experience quite remarkable progress both in terms of quantity and in terms of quality. In terms of quantity can be seen from the applying students who go to college is quite a lot, for example, at the Muhammadiyah University of Malang, 10 years ago it was very difficult to get students. Currently Muhammadiyah University of Malang have started to dare refusing a number of students because of high interest. In terms of quality, the number of lecturers who holds Professor, Doctoral and Master is also sufficient, learning systems have used system-based approach to information management. Based on the interviews conducted by the authors with the rector of Muhammadiyah University of Malang and Surabaya argued that universities in other parts of East Java also experienced the same progress (3) based on the initial study there was information that the lecturers' performance is quite good at certain Muhammadiyah University although the salary is still below standard of salaries and welfare of lecturers civil servants, while regarding the level of job satisfaction up to know most of lecturers are satisfied with work as it is considered as worship, but on the other hand there are also not satisfied with the reasons that the salary received less than adequate. (4) Muhammadiyah University is an Islamic values-based college growing besides having modern and contemporary organizational culture (5) the progress made by Muhammadiyah University in East Java is also not separated from the university administration's commitment in implementing the spirit of modern management and spirit of religion (Islam) which teaches the commitment of the truth, a commitment to honesty, commitment and desire to be trustful going forward. (6) In terms of theory development of this study, in the organizational culture variables the authors try to put some sub-variable that inspired by Islamic values with the consideration that has been much researches done on organizational culture based on religious values have not touched deeply on the things that are fundamental to understand the concept of work, such work is worship, work needs sincerity, appreciate the time an application of the basic principles of Islam, true and honest and be fair in the works is the demands of Islamic culture.

Based on the research background, the aim of this study was to describe: (1) positive and significant effect of organizational culture on lecturers' job satisfaction (2) positive and significant effect of job satisfaction on lecturers' performance (3) positive and significant effect of organizational culture on lecturers' performance (4) positive and significant effect of organizational culture on lecturers' performance through job satisfaction.

\section{Research Methodology}

Design used in this study is an organizational survey through cross-sectional studies.

The population of this study was all lecturers of Muhammadiyah University throughout East Java who have been worked over 3 years in hopes they already understand the organizational culture and organizational commitment, namely 1881 persons consisting the lecturers Muhammadiyah University of Malang 548 persons, Muhammadiyah University of Surabaya 334 persons, Muhammadiyah University of Sidoarjo 285 persons, Muhammadiyah University of Gresik 227 persons, Muhammadiyah University of Ponorogo 248 persons, and 


\section{$\Delta$ Macrothink}

Muhammadiyah University of Jember 239 persons.

By using the formula Fred N. Kerlinger (1998) as follows:

$$
\begin{gathered}
\mathrm{N} \\
1+\mathrm{Ne}^{2}
\end{gathered}
$$

Description:

$\mathrm{n}=$ sample size

$\mathrm{N}=$ size of the population

$\mathrm{e}=$ percentage of inaccuracy (precision) for making mistakes

on samples are still tolerated or desired.

With a population size of 1881 and the inaccuracy rate of $7 \%$ then the result is 184.81 or 185. Thus the sample size was 185 persons. However, according to Ferdinand in Zaini Hasan (2004) minimum requirement of samples in studies using SEM analysis was 100 to 200, then direct sample rounded to 200 . Once the sample size is known then to gather data used stratified random sampling technique.

Data were collected using questionnaires and interviews. Data analysis techniques applied SEM (Structural Equation Modeling) by using statistical software AMOS.

\section{Results}

3.1. Testing Hypothesis $\mathrm{H} 1$

Hypothesis H1 in this study stated that organizational culture significantly influence job satisfaction. This hypothesis was statistically associated with the test results $\gamma_{1}$ which can be formulated with statistical hypothesis:

$\mathrm{H}_{0}: \gamma_{1}=0$ There is no significant effect of organizational culture on job satisfaction

$\mathrm{H}_{\mathrm{a}}: \gamma_{1} \neq 0$ There is a significant effect of organizational culture on job satisfaction

Table 1. The Result of Hypothesis Test of Organizational Culture On Job Satisfaction

\begin{tabular}{|l|l|l|l|l|l|}
\hline One-way Path & $\begin{array}{l}\text { Coefficient } \\
\text { Regression }\end{array}$ & $\begin{array}{l}\text { Standard } \\
\text { Error }\end{array}$ & $\begin{array}{l}\text { Standard } \\
\text { Coefficient }\end{array}$ & C.R & p-value \\
\hline $\begin{array}{l}\text { Organizational } \\
\text { Culture }\end{array}$ & 0,187 & 0,087 & 0,181 & 2,148 & 0,032 \\
$\begin{array}{l}\text { Job Satisfaction } \\
\text { Sour }\end{array}$ & & & & \\
\hline
\end{tabular}

Sources: Primary data processed (2007)

Regression coefficient gamma $\left(\gamma_{1}\right) 0187$ by CR amounted to 2.148 and p-value 0.032 has proved that the regression coefficients obtained are different from zero, meaning that it has a positive and significant effect. The effect of organizational culture on job satisfaction can be received up to 0.05 significance level. This coefficient explains that the better the organizational culture is formed it will be able to increase job satisfaction. Regression coefficients in standard form on this relationship is equal to 0.181 . It is thus hypothesis H1 in this study stated that organizational culture significantly influencing job satisfaction is acceptable.

\subsection{Testing Hypothesis $\mathrm{H} 2$}

Hypothesis $\mathrm{H} 2$ in this study stated that organizational culture significantly affect the lecturers' performance. This hypothesis was statistically associated with the test results $\gamma_{2}$ 
which can be formulated with statistical hypothesis:

$\mathrm{H}_{0}: \gamma_{2}=0 \quad$ There is no significant effect of organizational culture on lecturers' performance

$\mathrm{H}_{\mathrm{a}}: \gamma_{2} \neq 0 \quad$ There is a significant effect of organizational culture on the lecturers' performance

Table 2 The Result of Hypothesis Test on The Effect of

Organizational Culture On Lecturers' Performance

\begin{tabular}{|l|l|l|l|l|l|}
\hline One-way Path & $\begin{array}{l}\text { Coefficient } \\
\text { Regression }\end{array}$ & $\begin{array}{l}\text { Standard } \\
\text { Error }\end{array}$ & $\begin{array}{l}\text { Standard } \\
\text { Coefficient }\end{array}$ & C.R & $p$-value \\
\hline $\begin{array}{l}\text { Organizational } \\
\text { Culture }\end{array}$ & 0,846 & 0,125 & 0,552 & 6,747 & 0,000 \\
$\begin{array}{l}\text { Lecturers' } \\
\text { Performance }\end{array}$ & & & & & \\
\hline
\end{tabular}

Sources: Primary data processed (2007)

Regression coefficient gamma $\left(\gamma_{2}\right) 0.846$ with CR 6.747 and p-value 0.000 has shown evidence that the regression coefficients obtained are different from zero, meaning that there is a positive and significant effect. The effect of organizational culture on lecturers' performance is acceptable up significance level 0.01. This coefficient has been able to explain that the better the culture of the organization will be able to improve the performance of the lecturers. Regression coefficients in standard form in this connection amounted to 0,552. Thus the hypothesis $\mathrm{H} 2$ in this study stated that organizational culture significantly affecting the performance of the lecturer is acceptable.

\subsection{Testing Hypothesis $\mathrm{H} 3$}

Hypothesis H3 in this study stated that job satisfaction significantly influence the performance of the lecturer. This hypothesis was statistically associated with the test results toward $\beta_{1}$ which can be formulated with statistical hypothesis:

$\mathrm{H}_{0}: \beta_{1}=0$ No significant effect of job satisfaction on lecturers' performance

$\mathrm{H}_{\mathrm{a}}: \beta_{1} \neq 0$ There is a significant effect of job satisfaction on lecturers' performance

Table 3. The Result of Hypothesis Test on

The Effect of Job Satisfaction On Lecturers' Performance

\begin{tabular}{|l|l|l|l|l|l|}
\hline One-way Path & $\begin{array}{l}\text { Coefficient } \\
\text { Regression }\end{array}$ & $\begin{array}{l}\text { Standard } \\
\text { Error }\end{array}$ & $\begin{array}{l}\text { Standard } \\
\text { Coefficient }\end{array}$ & C.R & p-value \\
\hline $\begin{array}{l}\text { Job Satisfaction } \\
\begin{array}{l}\text { Lecturers, } \\
\text { Performance }\end{array}\end{array}$ & 0,873 & 0,138 & 0,591 & 6,326 & 0,000 \\
\hline
\end{tabular}

Sources: Primary data processed (2007) 
Coefficient regression beta $\left(\beta_{1}\right) 0.873$ with CR 6.326 and p-value 0.000 (smaller than $\alpha$ $=0.05$ ) have shown evidence that the regression coefficients obtained are different from zero, meaning that there is a positive and significant effect. The effect of job satisfaction on the performance of the lecturers can be accepted at significance level 0.01 . This coefficient can be explained that job satisfaction is high will be able to improve the performance of lecturers. Regression coefficients in standard form on this relationship is 0.591 . It is thus the hypothesis $\mathrm{H} 3$ in this study stated that job satisfaction significantly affecting the lecturers' performance is acceptable.

\subsection{Testing Hypothesis $\mathrm{H} 4$}

Hypothesis $\mathrm{H} 4$ in this study stated that organizational culture has positive and significant effect on lecturers' performance through job satisfaction.

Hypothesis $\mathrm{H} 4$ associated with the test results of $\mathrm{H} 1$ and H3. Statistically, this hypothesis is related to test results toward $\gamma_{1}, \beta_{1}$, which can be formulated with a statistical hypothesis:

$\begin{aligned} & \mathrm{H}_{0}:\left(\gamma_{1}, \beta_{1}\right)=0 \begin{array}{l}\text { There is no significant effect of organizational culture on lecturers' } \\ \text { performance through job satisfaction }\end{array} \\ & \mathrm{H}_{\mathrm{a}}:\left(\gamma_{1}, \beta_{1}\right) \neq 0 \begin{array}{l}\text { There is a significant effect of organizational culture on lecturers' } \\ \text { performance through job satisfaction and } \mathrm{H} 4 \text { previously obtained results }\end{array} \\ & \text { that there is a significant effect of organizational culture on both job } \\ & \text { satisfaction and job satisfaction on the performance of the lecturer. It is thus } \\ & \text { H4 which states that organizational culture significantly influence the } \\ & \text { performance of lecturers through job satisfaction in this study can be } \\ & \text { proven. }\end{aligned}$

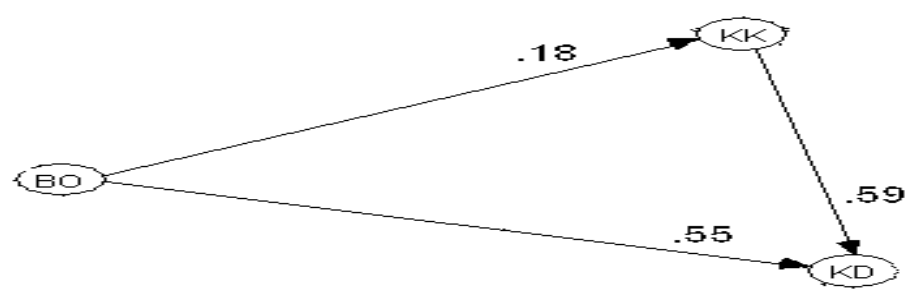

Image. 3.1. The Effect of Organizational Culture

On Lecturers' Performance Through Job Satisfaction

Direct and indirect effect of organizational culture on lecturers' performance can be explained in the following table.

Table 3.1. The Effect of Organizational Culture

On Lecturers' Performance Through Job Satisfaction

\begin{tabular}{|l|l|l|l|l|}
\hline Independent & Dependent & Direct Effect & $\begin{array}{l}\text { Indirect } \\
\text { Effect }\end{array}$ & Total Effect \\
\hline $\begin{array}{l}\text { Organizational } \\
\text { Culture }\end{array}$ & $\begin{array}{l}\text { Job } \\
\text { Satisfaction }\end{array}$ & 0,181 & - & 0,181 \\
\hline Organizational & Lecturers' & 0,552 & 0,107 & 0,659 \\
\hline
\end{tabular}




\begin{tabular}{|l|l|l|l|l|}
\hline \hline Culture & Performance & & & \\
\hline Job Satisfaction & $\begin{array}{l}\text { Lecturers' } \\
\text { Performance }\end{array}$ & 0,592 & - & 0,592 \\
\hline
\end{tabular}

Sources: Primary data processed (2007)

Based on the analysis in the table above can be explained that the direct effect of organizational culture on lecturers' performance 0,552 is far greater than the indirect effect through job satisfaction with a value of 0.107 .

\section{DISCUSSION}

\subsection{Cultural Organizations Have Significant Positive Effect On Lecturers'Job Satisfaction}

Understanding the effect of organizational culture positively and significantly on lecturers' performance is that the better the organizational culture built at Muhammadiyah University, the more increasing level of job satisfaction of lecturers. In this study the dimensions of cultural constructs that reflect organizational culture construct comprising of communication, training and development, benefits, decision-making, risk-taking, planning, cooperation, motivation to work, sincerity, discipline and appreciate the time, egalitarian spirit, order and carry out worship management practices. While the dimensions of constructs that are proven to establish construct of job satisfaction is composed of policy/organizational administration, supervision, working conditions, interpersonal relations, salary, job security, job performance, responsibility, opportunity to grow / develop, recognition of the work itself. Therefore empirically proven that organizational culture with various dimensions of constructs has an effect on lecturers' job satisfaction, therefore the rector should be able to create conditions conducive to the growth and development of cultural dimensions of the construct. In fact in educational institutions based on Islamic values, the development of organizational culture is not enough to just base ourselves on the Western theories, however, the organizational culture must also be derived from the values or beliefs of religious adherents of the majority of members of the organization.

The result of the study is actually in line with research findings that conducted by Hamida (2001) in research on Islamic financial institution employees Baitul Mal wat Tamwil (BMT) in Blitar. Conclusion of the research stated that organizational culture based on Islamic values has significant effect on job satisfaction of BMT employees. Recent research conducted by Sangadji, (2005) also concluded that there is a significant effect of organizational culture on job satisfaction of teachers of economics in Surabaya, Malang and Jember. Dimensions of cultural constructs that empirically reflect construct of organizational culture is the orientation of results and development of human resources, while the dimensions of job satisfaction constructs that reflect the teachers' job satisfaction is job factors and co-worker relationships. Theoretically, this finding is also in line with research findings by Ritchie (2000) which states that organizational culture applied in the form of the spread of organizational values is most strategic to develop employees' trust in the organization. Alfiliulahtin (2006) in her research on the effect of organizational culture on trust in the organization concluded that culture has significant and positive direct effect on lecturers' trust in the college, in a study conducted at private universities in East Java. The results of this study showed that although the dimensions of constructs that reflect the organizational culture construct is different in each study, but the results of the study concluded that organizational cultural variables continue to have significant 
effect on employees' job satisfaction. The results of this study also supports research by Watanabe (2005) that suggested some of the prominent features of the prevailing culture within the Muhammadiyah organization starting since its inception until now derived from the values of the Qur'an and Sunna very encouraging rapid development of Muhammadiyah organization compared to another Islamic organizations in Indonesia are: (1) the existence of the spirit of renewal, always questioning the substance of an issue whether it be religious or muamalah (2) egalitarian spirit, no blue blood culture in the Muhammadiyah organization, thus encouraging the organization more easily solving the problem (3) uphold the values of sincerity, simplicity, honesty and justice (4) spirit of deliberation (5) always precede rational consideration in solving the problem (6) organizational management practices in modern organizations have been enforced. The characteristics of modern organizations are: the organization has articles of association (AD), Household Budget (ART) and other organizational rules, regularly make work program and budget of the Organization program clearly and be clearly accountable (6) the presence of mutual respect spirit if occurrence of dissent. It would make the Muhammadiyah organization never profit organization to promote this or in the language of organizational behavior, organizational culture greatly influence job satisfaction of managers. If in the case of colleges, therefore organizational culture deeply affect lecturers' job satisfaction.

\subsection{Organizational Culture Has Significant and Positive Effect On Lecturers' Performance}

The results of empirical analysis suggests that organizational culture does not only affect lecturers' job satisfaction but also directly affects the performance of lecturers. Logical consequence of this finding is all the elements involved in the organization of Muhammadiyah University shall have the same responsibility to build a healthy organizational culture. The more healthy organizational culture will improve lecturers' performance. Many of the research findings conducted elsewhere as done in Indonesia by Sani (2001), Amirudin (2002), Khoirul (2002), performed abroad by Hodge \& Anthony (1994), Juechter, et.al. (1998). Meanwhile Deal \& Kennedy (1982) and Peter \& Waterman (1982) in Sobirin (1997), states that the better the organizational culture of an organization, the better the performance of the members of the organization, because the members of the organization to join and want to work in an organization actually is not just want to get the financial needs alone, but he wanted to work comfortably with the situation, that according to the terms Robbins (2001) is synonymous with the culture of the organization. When a person feels uncomfortable in working for the organization's culture is not conducive therefore the worst consequences was that he would take the fight in the form of apathy, high absenteeism, there is no initiative, the strike will even come out the organization and move into the other one although compensation received from other organizations is much lower.

Furthermore Syafii (2005) explained that there is a very distinctive culture that encourages rapid growing Muhammadiyah organization including Muhammadiyah university, namely (1) the experience and willingness to accept new ideas (2) democratic in accepting the views of others (3) have a very big concern on planning, efficiency, visionary and belief in upholding justice, such an attitude is growing among traders and middle class town that a lot of moving and carrying out Muhammadiyah organization. So it is not wrong if the term Tajdid or updates to the main spirit of the Muhammadiyah movement. Tajdid according Kuntowijoyo (2002) is an attempt to combine faith and encouraged by the spirit of progress purifying timeless values releasing cultural burden attached to the institutionalization of the values of Islam and dressed again with new cultural values. The use of this value serving as organizational culture in a very progressive Muhammadiyah unions can encourage Muhammadiyah youngsters especially the lecturers to always improve self-quality so that its performance be improved. The most current example is in 
2007 the lecturers of Muhammadiyah University of Malang able to get about 70 research grants in the Director General of Higher Education (Java Post, 26 April 2007)

\subsection{Job satisfaction has significant positive effect on lecturer's performance}

The results can be interpreted as the more satisfied a lecturer working in Muhammadiyah University the better the performance. The findings of this study support research by Rao (1996) that there are some things that can make employees more willing to perform the work, as the impact of job satisfaction he gained, namely: (1) the employee will work hard if felt necessary by the organization (2) employees will work better if they are clear about what is expected of them and when they occasionally authorized to change those expectations (3) employees will work better if they feel that the organization provides opportunities for their performance to be appreciated and rewarded (4) the employee will work if they know that the organization provides opportunities to develop and use their abilities as far as possible, and (5) the employee would have worked better if they believed and treated with respect. Or in other words, employees want to work because they were pleased with his work and will further impact on their performance.

Empirical studies related to job satisfaction was also done by the American National Work at The Wyatt Company (Robbins 1996). This study identifies 12 dimensions of job satisfaction that influence employee performance, namely: the organization of work, working conditions, communication, job performance and the performance of the review, co-workers, supervision, management companies, wages, benefits, career development and training, content and job satisfaction, as well as corporate image and change. The results of this study concluded that subordinates' job satisfaction is deeply affected their performance, when they are not satisfied then their performance decline, they can even lead to stress or frustration. This finding also supports the findings of Ery Tri Djatmika (2005) that job satisfaction positively influence the behavior of economic school teachers in the city of Surabaya, Malang and Jember. And research findings of Rumapea Patar (2005) that the more satisfied a teacher, the better the performance of teachers in northern Sulawesi.

\subsection{Organizational culture has significant positive effect on lecturers' performance through} job satisfaction

The result of the study states that organizational culture significantly affect lecturers' performance through job satisfaction. The results are consistent with the findings of research conducted by the Church, and Zikic (2004) the suitability of organizational culture will be able to reduce the occurrence of conflict, either work-related or related to the relationship between the individual, the minimization of conflict in the organization is a manifestation of increased job satisfaction employees, they are satisfied with the impact on improving their performance. Following that finding Tepeci (2001) revealed that organizational culture affect the level of job satisfaction is realized in the form of a desire to remain level in the organization, and the willingness to provide the best for the organization so as to improve overall organizational performance. So are the findings of Rashid, Sambasivan, and Johari (2003) that organizational culture is closely related to employees' satisfaction and significant effect on the achievement of performance. For the sake of the future, suitability and transparency of organizational culture plays an important role for the success of the organization doing the processes of change, organizational learning, and social learning (Rashid, Sambasivan, and Rahman, 2003; Ladd and Heminger, 2002; Ali, Pascoe and Warne, 2002). Especially for public organizations, in order to enhance the competitive value, it would require an organizational culture that is able to move from models of public administration more open, as it has been done by private sector organizations so as to encourage the growth and development of employees' job 
satisfaction which in turn led to an increase in the performance of members of the organization (Parker and Bradley, 2000).

According to Ouchi (in Ogbor, 2001), organizational culture is a necessary means to create a harmonious working relationship in which the values and common beliefs reduces the likelihood of opportunistic behavior. Organizational culture is important because in the event of ambiguity, the common values and beliefs will be a regulatory mechanism. From the integrative perspective, the prevailing values hold together as cohesiveness binder of organization member. Peters and Waterman (in Ogbor, 2001) suggests that organizational culture is required to keep in case of ambiguity and paradox. Ogbor (2001) argues that the organizational culture who gives a sense of work comfort and trust who high will encourage an increase in work behavior through of the high cohesiveness inter-individuals and commitment from citizens organizations to do everything on who best for the interests of the organization.

While the study of Hofstede (in Brooks, 2004 and in Robbins, 2003; Hofstede, 2004) suggests that the cultural dimension is very coloring activities including such everyday activities in the world of work includes five kinds, namely the level of power distance, individualism-collectivism, uncertainty avoidance, masculinity-femininity, as well as the notion of time (time horizon). The dimensions of organizational life greatly affect the relationships between people, including between superior-subordinate, the intensity of personal ties, the treatment of the gender, as well as attention to the dynamics of the time.

Mar'at (1992) argues that in broad outline employees' performance is affected by two factors, namely: (1) individual factors, and (2) situational factors (organizational culture). Each individual has different characteristics, such as physical form, ability, personality, motivation, needs, expectations, etc.. This characteristic differences will have an impact on the difference in his performance. While on the other hand, the work situation, such as working conditions, facilities and infrastructure work, work systems, work culture, leadership style developed in the organization, the communication that occurs in the organization, relationship with other individuals, all affect on employee performance . Reech (1989) adds that the employee's performance can be affected by an individual employee motivation, satisfaction with intrinsic and extrinsic rewards, and culture developed by the organization, which in turn affects the performance of members of the organization.

Each individual has different characteristics, such as physical form, ability, personality, motivation, needs, expectations, etc. This characteristic differences will have an impact on the difference in his performance. While on the other hand, the work situation, such as working conditions, facilities and infrastructure work, work systems, work culture, leadership style developed in the organization, the communication that occurs in the organization, relationship with other individuals, all affect on employee performance. Reech (1989) adds that the employee's performance can be affected by an individual employee motivation, satisfaction with intrinsic and extrinsic rewards, and culture developed by the organization, which in turn affects the performance of members of the organization

To measure employees' performance, there are many ways we can do. For example, Sharif (1987) suggests that to measure employee performance should be the quality of work (smoothness, accuracy, and cleanliness), the amount of time required, the number of types of tools (skills in using a variety of tools), and knowledge of the job. Bernandin and Russel (1995), suggests there are six primary criteria that can be used to measure employees' performance, namely: (1) quality, is the extent to which, or the results of the implementation process of approaching perfection or close to the expected goals (2) quantity, is the amount produced, for example, the amount of dollars, number of units, or the number of cycles completed activities (3) timeliness, duration of an activity is completed at a desired time, taking into account the number of other outputs as well as the time available for other activities (4) cost effectiveness, the magnitude of the use of resources in order to achieve maximum results from the loss or reduction of each unit of resource use (5) need for supervision, the employee's 
ability to perform job functions without requiring the supervision of a supervisor to prevent actions that are less desirable (6) interpersonal impact, an employee's ability to maintain self-esteem, reputation and ability of cooperation among co-workers and subordinates.

According Helriegel and Slocum (1996), each individual is a unique individual who is not the same from one individual to another individual. Such differences as the terms of the needs, desires, values, attitudes, norms adopted, abilities, interests, talents, interests, hopes, ideals, etc. Because of these differences, it is natural that the performance or individual performance (employee) may also differ between one individual with another individual. Job characteristic is a job trait that limits the responsibilities and challenges. The job characteristics include: (a) the type of skills required (2) task identity (c) the individual contribution to the work, (d) autonomy, and (e) individual feedback received from their work. Each job or position has characteristics different jobs. Consequently each job requires qualified employees (competency) different for the office holders or the job. When an employee feel certain characteristics of his work requires qualifications which he could not do, then the employee's performance will be low. On the other hand for example, when employees feel they have a clear autonomy in his job then he will have a low work motivation. Also if the employee does not obtain feedback or good feedback from the management after the performance is assessed, then the employee's work motivation will be low.

Furthermore Rao (1996) adds that there are some things that can make employees want to perform better at work, namely: (1) The employee will work hard if felt necessary by the organization (2) Employees will work better if they are clear about what is expected of them and if they occasionally authorized to change those expectations (3) Employees will work better if they feel that the organization provides opportunities for their performance to be appreciated and rewarded (4) Employees will work if they know that the organization provides opportunities for develops and as far as possible to use their abilities and (5) The employee would have worked better if they believed and treated with respect. Or in other words because employees want to work in a good organization culture effect and impact on satisfaction with the work itself, which in turn will affect their performance.

Because empirically the formulated hypothesis proven therefore college administrators of Muhammadiyah should pay more attention to be able to build the various dimensions of organizational culture and lecturers' job satisfaction construct with various dimensions in order to be able to encourage the improvement of lecturers' performance. Job satisfaction is obtained as a healthy culture, the culture that built the system should be based on a combination of values on the traditional value of the organization and the transcendent value of an organization modernity. The values consist of: communication, training and development, compensation, decision making, planning, cooperation, motivation to work, sincerity, discipline and appreciate the time, egalitarian spirit, order in carrying out worship, practice management. While the dimensions of job satisfaction should be seriously considered is the policy/organizational administration, supervision, working conditions, interpersonal relations, salary, job security, responsibility, opportunity to grow/develop, recognition, work itself.

This study also found a direct effect of organizational culture on performance that is greater than the indirect effect through job satisfaction on lecturers' performance. This may happen due to a strong presumption that in the dimensions of job satisfaction construct there is certain dimensions of job satisfaction namely job performance that did not participate in forming the construct of job satisfaction, so that had an impact on the value of the indirect effect of organizational culture on lecturers' performance becomes smaller. Logical consequence of this finding is that the college should pay attention to proportional reward for lecturers' performance which can be manifested in the form of the provision of equal opportunities for all lecturers to continue their studies at a higher education level or the same promotion policies to all lecturers with priority consideration of lecturers' achievement. 
Descriptively it is also found out that factors of reward for achievement considered still very deficient number in Muhammadiyah University.

\section{Conclusion}

The results of the research conclude: (1) There is positive and significant effect of organizational culture on lecturers' job satisfaction (2) There is positive and significant effect of job satisfaction on lecturers' performance (3) There is positive and significant effect of organizational culture on lecturers' performance (4) There is positive and significant effect of organizational culture on lecturers' performance through job satisfaction.

\section{References}

Abdullah, Taufiq, 1980, Agama, Etos Kerja dan Perkembangan Ekonomi, LP3ES, Jakarta

Alfiliulahtin (2006) The effect Organizational Culture to Job Stasifaction, Thesis, PPS Universitas Brawijaya Malang

Al-Qur'an dan Terjemahan, (2005) Mujamma' Al Malik Fahd Li Thiba'at Mus-

haf Asy-Syarif Medinah Munawwarah, Kerajaan Saudi Arabia

Alwi,Syafaruddin, 2001. Manajemen Sumberdaya Manusia Strategis, BPFE,

Yogjakarta

Amstrong, M. 1996. Manajemen Sumber Daya Manusia. Jakarta: PT Elex Media

Komputindo.

Anderson, J. C. dan Gerbing, D. W. 1991. Structural Equation Modelling in Practice: A Review and Recommended Two-Step Approach. Psychological Bulletin, 193(3), pp. 411- 423.

Arbucle, James L., dan Wothke, Warner, 1995-1999, AMOS 4, User Guide, Small Water Corporation

As'ad, M. 1998. Psikologi Industri. Yogyakarta: Liberty.

Atmosoeprapto, Kisdarto. 2001. Produktivitas Aktualisasi Budaya Perusahaan. Penerbitv Elex Media Komputindo.Jakarta.

Bernandin, H., John \& Russel, Joyce E.A. 1993. Human Resources management

Singapore: Mc. Graw-Hill Inc.

Berry, Lilly M. 1998. Psychology at Work, An Introduction to Organizational

Psychology. Singapore: Mc. Graw Hill International Edition.

Brooks, I., 2004, Organizational Behaviour, Individuals, Groups an

Organisation, Harlow, England, Prentice Hall, Pearson Education Limited

Cats-Baril and Thompson. 1995. Managing Information Technology Projects in the Public

Sector. Public Administration Review. November/December 1995. Vol. 55. No. 6

Challan, R.E. Fleenor, C.P dan Knudson, H.R. 1986, Understanding

Organizational Behavior, a managerial Viewpoint, Colombus, Ohio:

Charles E. Merrill Publishing Co., A Bell \& Howell Company

Chapra, Umer, M, 2000, Islam And Enomomic Challenge, (Islam Dan Tantangan

Ekonomi) Gema Insan Pers, Jakarta

Charrington, D.J. 1994. Managing of Human Resources. Third Edition. Boston:

Allyn Bacom.Cooper, Donald R. \& William Emory. Business Research

Method. Terjemahan: Sitompul dkk.Jakarta: Erlangga.

Coopey, J. and J. Harley. 1991. Reconsidering The Case of Organizational

Commitment.Human Resources Management Journal. Vol 1.3. 
Davis, Keith \& Newstrom, John W. 1985. Perilaku Dalam Organisasi, edisi Bahasa Indonesia, Alih Bahasa Agus Dharma, S.H.,M.Ed., Penerbit Erlangga.

Desler, Gary. 2003. Organizational Theory Integrating Structurre and

Behavioral. Second Edition. Prentice Hall.

Dharma, A. 1985. Manajemen Prestasi Kerja. Edisi 1. Jakarta: Rajawali.

DIRJEN DIKTI, DEPDIKNAS, Republik Indonesia, 2004, Jabatan Fungsional

Dosen Dan Angka Kreditnya, Jakarta

Djarwanto, P.S. dan Subagyo. 1991. Statistik Induktif. Yogyakarta: BPFE.

D. Infokom. Jatim. 2001. Profil Jatim (online). (http: //www.d.Infokom-Jatim).

Drucker, P.F. 1996, The Leader of The Future, terjemahan Bob Widyahartono,

Gramedia, Jakarta

Emory, C. William Cooper, Donald, R. 1991. Business Resources Methods. Fourth

Edition. Illinois: Richard D. Irwin, Inc..

Ellitan, L Tantangan dan Perubahan Peran Manajemen Sumber Daya Manusia

dalam Menghadapi Perubahan Lingkungan dan Isu-Isu Bisnis yang

Berkaitan dengan Sumber Daya Manusia. 1999. Widya Humanika. Vol. 7.

Faisal, S. 1989. Format-Format Penelitian Sosial, Dasar-Dasar dan Aflikasi.

Jakarta: Rajawali

Ferdinand, A. 2000. Structural Equation Modelling dalam Penelitian Manajemen.Semarang:

Badan Penerbit universitas Dipenogoro.

Fieldman, Daniel C. \& Arnold, Hugh J. 1983. Managing Individual and Group

Behavior in Organization. Mc. Graw-Hill Series in Management.

Gibson, Ivancevich \& Donnely. 1996. Organisasi, Perilaku, Struktur-Proses,

Edisi kedelapan. Binarupa Aksara.

Godman, P. Pichman, M. Lerch, F. and Syders,P. 1995. Customer - Firm

Relationships, Involvement and Customer Satisfaction. Academy Journal.

38. 1310-1324.

Gordon, J.R. 1991, A Diagnostic Approach to Organizational Behavior, Boston:

Allyn and Bacon

Hair, F. Jr., Rolph, E. A. Romald, L.T. dan William, G.B. 1998. Multivariate

Data Analysis. Fifth Edition. New Jersey: Prestice Hall International, Inc.

Hamidah, Siti, 2001, The effect Organizational Behavior to Employees

satisfaction of BMT, Thesis, PPS, Universitas Brawijaya Malang

Handoko, Hani T. 1998. Manajemen Personalia dan SDM. Liberty. Yokyakarta.

Hasan, Z. 2001. Analisis Jalur. Makalah Disajikan dalam Lokakarya Statistik dan

Analisis Data Penelitian dengan Komputer Angkatan X11 2001/2002. Lemlit UM.30 Januari 1 Maret 2001.

Hasibuan, Malayu, S.P. 1994. Manajemen SumberDaya Manusia: Dasar dan

kunci Keberhasilan. Jakarta: CV Haji Masagung.

Haneman, Robert, L. \& David B. 1988. The Relationship Between Pay for

Performance Perception \& Pay Satisfaction. Personal Psychology. Vol 1.2.

Hellriegel, Don and John W. Slocum, Jr. 1996. Management. USA: South Western

College Publishing.

Husein, M. Fakhri dan Amin Wibowo. 2002. Sistem Informasi Manajemen. Edisi revisi . Unit Penerbit dan percetakan AMP YKPN .Yogyakarta

Ibrahim Bin Hamd Al-Qu'ayyid, 2003 Al Adaat Al Asyr Li Asy Syakhshiyah An

Naajihah (Sepuluh kebiasaan Muslim Yang sukses), Jakarta, La Tansa Bima Amanta

Jamilah, Maryam, 2004, Para Mujahid Agung, Bandung, Mizan

Jernigan, I.E. III, Joyce M. Beggs and Gary F. Kohut. 2002. Dimensions of Work

Satisfaction as Predictors of Commitment 
Jennifer, A. C. and Jehn Karen A. 1994. Assesing The Relationship Between Industri Characteristics and Organizational Culture: How Different Can ou Be?. Academy of Management Journal. Vol 37. 34.

Jogiyanto HM.,MBA.,Akt.,Ph.D. 2005. Analisis \& Disain Sistem Informasi : Pendekatan Terstruktur teori dan praktek aplikasi bisnis. Penerbit Andi Yogyakarta.

Joreskog, Karl G., \& Sorbom, Dag. 1982. "Recent Developments in Strultural Equation Modeling, Journal of Marketing Research, Vol. XIX (November), pp. 406-416.

Judge T. A.and Shiniciro Watanabe. 1993. Another Look et The Job Satisfaction Life Satisfaction. Journal of Applied Psychology. Vol 78. No 6.

Kanter, A. 1986. Human Resources Management. Terjemahan Jakarta: PT Bratama Media.

Kerlinger, Fred. N. 1996. Azas-Azas Penelitian Behavioral. Edisi Ketiga. Edisi

Bahasa Indonesia. Gajah Mada University Press.

Khoirul, Muhammad, 2002, Pengaruh Budaya Organisasi terhadap Kinerja Dosen

Universitas Muhamadiyah Malang, Lempada Penelitian, Universitas

Muhammadiyah Malang

Kompas New Spapeper,, 3 Januari, 2005

Kuntowodjojo, 2002, Muhammadiyah Sebagai gerakan Tajdid, Universitas

Muhammadiyah Yogjakarta

Lawler,E. 1986. High - Involvement Management. Sanfransicco: Jossey Bass.

Lin, Sh. T. An Tien Hsueh. 2002. Constraints of Task Identity on Organizational

Commitment. International Journal of Manfower. Vol.13.11.

Lopez, Elsa. 1982. A Test of The Self. Consistency: Theory of the Job Performance

- Job Satisfaction Relationship. Academy of Management Journal Vol 25.2.

Luth, Thohir,2001, Antara Perut Dan Etos Kerja Dalam Perspektif Islam, Gema

Insan Pers, Jakarta

Luthans, Fred. S. 1995. Organizational Behavior, Seventh Edition. Singapore: Mc.

Graw Hill.

Luthans, Fred. S. 2002. Organizational Behavior. Tokyo: Mc. Graw Hill

International Book Company.

Madjid, Nurcholis, 1987, Islam Kemoderenan Dan Keindonesiaan, Bandung,

Mizan

Malhotra, N.K. 1996. Marketing Research. London: Prentice Hall. International ,Inc

Mar'at, M. 1982. Sikap Manusia, Perubahan dan Pengukurannya. Jakarta: PT

Gunung Agung.

Max Weber, 2001, Etika Protestan Dan Semangat kapitalisme, Jakarta, Pustaka

Promethea

Moynihan L.M. et al. 2001. H.R. Practices and Customer Satisfaction: The

Mediating Link of Commitment. Journal of H.R. Practices \& Customer

Satisfaction.

Mathis, R. 1. \& Jackson J.H. 2000. Human Resources

Minner, John B. 1997. Industrial and Organizational Psychology. Mc. Graw Hill International Edition.

Miller, K.L. and Monge, P.R. 1986. Participation, Satisfaction and Productivity: A Meta-Analitic Review. Academy of Management Journal. Dec. pp. 748 - 759.

Mondy, R.W. Noe, .M. 1993. Human Resources management. USA: Allyn \& Bacon Inc. 
Moshavi, D. dan Terborg, J.R. 2002, the Job Satisfaction and Performance of contingent and Reguler Customer Service Representatives, a Human capital Perspectives, International Journal of Service Industry management, 13 (4), 333-347.

Moenir, A.S. 1987. Pendekatan Manusiawi dan Organisasi Terhadap Pembinaan Pegawai. Jakarta: PT Gunung Agung.

Mulyasa, E. 2003, Menjadi Kepala Sekolah Profesional, Remaja, Rosdakarya, Bandung

Nakamura, Mitsuo,2005, Muhammadiyah Faces the Challenge of Democracy, Jakarta, KOMPAS dan STIE Ahmad Dahlan

Nawawi, H. 1998. Manajemen Sumber Daya Manusia Untuk Bisnis yang

Kompetitif. Yogyakarta: Gajah Mada University Press.

Newstorm, D.K., John. 1996. Perilaku Dalam Organisasi, Jilid I. Edisi Kedua Terjemahan: Agus Dharma. Jakarta Erlangga.

Newstroom, John W. \& Davis, K. 1989. Organizational Behavior, Reading \& Exercise. Eight Edition. Mc. Graw-Hill International Edition.

Nimran, Umar, 1999, Organizational Behavior, Citra Media, Surabaya

Ogbor, J.,O, 1999, Critical Theory and the hegemony of Corporate Culture, Journal Of Organizational Change, 14 (6), 590-608

Pidarta. 19992. Pemikiran tentang Supervisi Pendidikan.Jakatra: bumi Akasara. Pimpinan Pusat Muhmamadiyah, 2002, Kumpulan Qaidah Muhammadiyah, Jakarta PP Muhammadiyah Pimpinan Pusat Muhmamadiyah, 2002, Pedoman Hidup Islami Warga Muhammadiyah, Yogjakarta, Suara Muhammadiyah

Rashid, M.Z.A. Sambasivan, M., dan Johari., 2004, The Influence of Organizational Culture on Attitudes Toward Organizational Change, The Leadership \& Organizational Development Journal of Manpower, 23 (2) 137-150

Renaud, S., 2002, Rethinking the Union Membership/job Satisfaction Relationship, Some Empirical Evidence in Canada, International Journal of manpower, 23 (2) $137-150$

Rao, T.V. 1996. Penelitian Prestasi Kerja: Teori dan Praktek, Cetakan Ketiga. Terjemahan: Ny. L. Mulyana. Jakarta: Pustaka Binawan Pressindo.

Ricardo, Ronald and Jennifer, Jolly, 2003, Organizational Culture and Teams. Academy of Management Journal. Vol. 32. no. 5. 271-279.

Robbins, S. 2000. Perilaku Organisasi. Edisi Bahasa Indonesia. Jilid 1. Jakarta: PT Prehallindo.

Robbins, S.. 1996. Perilaku Organisasi Konsep - Kontroversi-Aplikasi . jilid II. Edisi Bahasa Indonesia. Jakarta: T Prenhallindo.

Robbins, S.. 2003. Teori Organisasi, Struktur, Desain, Aplikasi. Edisi 3. Terjem. Jusuf Udaya. Penerbit Acan.

Rodwell, John J. Rene Kienzle \& Mark A. Shadur. 1998. The Relationship Among Work Related Perceptions Integral Role of Communication. Human Resources Management Journal. Vol.37. 3.

Santoso, Singgih, 2000, Buku Latihan SPSS untuk Statistik Parametrik, PT Elex

Media Komputindo, kelompok Gramedia, jakarta

Sariati, Ali, 1988, Ideologi Kaum Intelektual, Mizan, Bandung

Sarker, S.J. Crossman, A., dan Chinmeteepituck, P., 2003, The Relationship of Age and Length of Service with Job Satisfaction: an Eximination of Hotel 
Employees in Thailand, Journal of managerial Psychilogy, 18 (7) 745-758

Sangadji, E.M. 2004, The effect organization culture to Theacher Satisfaction in

Malang, STKIP PGRI Pasuruan

Schwepker, C.H. Jr. and Thomas N. Ingram. 1996. Improving Sales Performance

Through Ethics: The Relationship between Salesperson Moral Judgement and Job Performance. Journal of Business Ethics. Vol. 15. 1151-1166.

Shobran, Sudarno, 2003, Budaya Organisasi Muhmmadiyah Dalam Kiprahnya dalam Membangun Indonesia, Jurnal Ilmu Dan Kemanusiaan, Majelis,

DIKLITBANG PP Muhammadiyah, Yogjakarta

Sharma, S. 1996. Applied Multivariate Techniques. first edition. New York: John

Wiley\& Sons.

Simamora, H. 1995. Manajemen Sumber Daya Manusia. Edisi 1 Cetakan 1.

Yogyakarta YKPN.

Sobirin, Ahmad, 1977, Organizational Culture, Konsep, Kontroversi dan

Manfaatnya Untuk Pengembangan Organisasi, JAAI Vol. 1 No. 2.

September, 152-185

Soeprihanto, John. 1998. Penilaian Kinerja dan Pengembangan Karyawan. Edisi Pertama.Yogyakarta: BPFE..

Steers, (dalam Dessler). 1992. Efektivitas Organisasi. Cetakan Pertama. Terjem: Magdalena Jamin. Jakarta: Erlangga.

Steers. Richard M. Lyman W. Porter. 1991. Motivation and Work Behavior. Fifth Edition. Mc. Graw-Hill International Edition.

Stoddard, Lothrop, 1966, The New World of Islam (Dunia Baru Islam), Djakarta, Sekretariat Negara Republik Indonesia

Stoner, J.A.F. Freeman, R.E.and Gilbert Jr. 1996. Management. Edisi Bahasa

Indonesia. Terjemahan: Alexander Sudiro. Jakarta: Prenhalindo.

Stum, David. 1998. Five Ingrediens for an Employee Retention Formula. Journal of Human Resources Focus. Vol 75.

Spector, Paul E. 1997. Industrial and Organizational Psychology, Research \& Practice. New York: John Wiley Sons Inc.

Steffen, Teresa, M. Nystrom, Paul C. 'Connor, Stephen . 1996. Satisfaction with

Nursing Homes. Journal of Health Care Marketing. Vol 16.

Sugiyono. 1999. Metode Penelitian Bisnis. Bandung: Alvabeta.

Sulivan, J.J. 1991. Three roles of Language in Motivation Theory, (dalm Richard M. Steers dan Lyman W. Porter, editor, 1991, Motivation and Work

Behavior) New York: Mc Graw-Hill, Inc

Syafiq, A.,Mughni, dkk, 2005, Menembus Benteng Tradisi, Sejarah

Muhammadiyah Jawa Timur, 1921-2004, Surabaya, Hikmah Press

Syarif, R. 1987. Teknik Manajemen Latihan dan Pengembangan. Jakarta : Ghalia

Indonesia.

Syafii, Maarif, M, 2005, Merajut Pemikiran Melangkah Untuk Aksi, dalam

Mitsuo Nakamura, Muhammadiyah Menjemput Perubahan, Jakarta,

KOMPAS

Tasmara, Toto, 2002, Membudayakan Etos Kerja Islami, Gema Insani Pers, Jakarta

Timoty A. Judge and Shiniciro Watanabe. 1993. Another Look et The Job Satisfaction - Life Satisfaction. Journal of Applied Psychology. Vol 78. No 6.

Tjiptono, F. Dan Diana, A. 1998, Total Quality Mannagement, Andi Offset, 
Yogjakarta

Umar, Husein. 1999. Riset Sumber Daya Manusia Dalam Organisasi. Jakarta:

Gramedia Pustaka Utama.

Viswesvaran, Chockalingam, Despandhe, Satish P. 1996. Ethics, Succes and Job

Satisfaction: A Test of Dissonance heory in India. Journal of Business Ethics. Vol. 15.

Wanous J. \& Edwars E. Lawler. 1982. Measurement Meaning of Job Satisfaction.

Journal of Applied Psychology. 12.

Wanous J. \& Edwars E. Lawler. 1982. Measurement Meaning of Job Satisfaction.

Journal of Applied Psychology. 12.3.

Wexley, K.N. \& Yukl, G.A. 1992. Perilaku Organisasi dan Psikologi

Perusahaan.Terjemahan: Shobarudin. Jakarta: Rineka Cipta

Wilk, Leslie, A. Redmon, William, K. 1998. The effects of Feedback and Goal

Setting on Productivity and Satisfaction of University Administration Staff. Journal of Applied Psyachology. Vol. 18. pp 45- 68.

Wood, J., Wallace, J., Zeffane, R.M., Kennedy D.J., Schermerhorn Jr., J.R., Hunt, J.G., Osborn, R.N. 1988, Organizational Behavior, an Asia Pasific

Perspektictive, Brisbane: John Willey \& Sons

Yavas U. and Bodur ,. Satisfaction Among Expatriate Managers: Correlation

and Consecuences. Journal of areer development

Yunan, Helmi, M., 2005, Teologi Muhammadiyah, Cita Tajdid dan Realitas

Sosial, Jakarta. UHAMKA PRESS 